\title{
SUITABILITY OF THREE NEWLY RELEASED KENYAN POTATO VARIETIES FOR PROCESSING INTO CRISPS AND FRENCH FRIES
}

Ooko GA ${ }^{1 *}$ and JN Kabira ${ }^{2}$

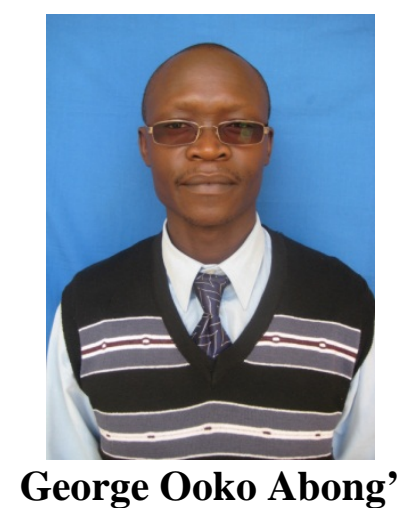

*Corresponding author email: georkoyo@yahoo.com

${ }^{1}$ Department of Food Science, Nutrition and Technology, University of Nairobi, P.O. Box 29053-00625, Nairobi (Kangemi), Kenya.

${ }^{2}$ National Potato Research Centre (KARI), Tigoni, P.O. Box 338, Limuru. Kenya. 


\section{ABSTRACT}

French fries and potato crisps are the most consumed industrially processed potato products in Kenya, especially in the major urban centers. Processors have, however, complained of the inadequate supply and low quality of potatoes currently available in the market. This study was instituted to evaluate the suitability of three newly released Kenyan potato varieties for processing. The three new potato varieties (Purple Gold, Kenya Mpya and Sherekea) and two established varieties (Tigoni and Dutch Robjin) used in this study were grown under standard conditions at the National Potato Research Centre, Kenya. They were harvested at maturity, cured and analyzed for physico-chemical characteristics and processed into crisps and French fries for suitability evaluation. All the cultivars had tuber sizes within recommended range for crisps $(40-60 \mathrm{~mm})$ and French fries $(\leq 45 \mathrm{~mm})$. Dry matter contents differed significantly ( $\mathrm{P} \leq 0.05)$ among the varieties ranging from $20.81 \%$ in Golden Purple to $25.77 \%$ in Kenya Mpya. Crisps oil content varied significantly $(\mathrm{P} \leq 0.05)$ from 31.28 \% in Kenya Mpya to 36.8 \% in Golden Purple while it ranged from $7.51 \%$ to $8.81 \%$ in French fries of the same varieties. Dry matter content was negatively correlated to oil contents of crisps and French fries. Significant $(\mathrm{P} \leq 0.05)$ varietal differences in color and textural properties of crisps and French fries were noted. Kenya Mpya, Tigoni, Sherekea and Golden Purple in that order of preference could be used to produce crisps that are comparable to Dutch Robjin, an established crisping variety in the local market. With the exception of Kenya Mpya, varieties Sherekea, Dutch Robjin and Golden Purple produced good quality French fries comparable to the established chipping variety, Tigoni. Potatoes from the new varieties are expected to form an additional pool of raw material for processing in Kenya and should be promoted alongside the established ones to support the growing industry.

Key words: Performance, varieties, crisps, French fries 


\section{INTRODUCTION}

Potato is an important food and cash crop that plays a major role in food security. The crop is rated second to maize in terms of utilization in Kenya [1]. Production in the country is confined to the highlands, where the crop performs better in terms of yield in comparison to other staple foods including maize. French fries and potato crisps are the most consumed industrially processed potato products in Kenya, especially in the major urban centers [2, 3]. Processors have, however, complained of inadequate supply and low quality of potatoes currently supplied in the market [4].

Many potato varieties are currently grown and marketed in Kenya. In addition, newer potato varieties and clones are developed by the National Potato Research Center (KARI-Tigoni) presumed to be superior to the existing ones in terms of disease tolerance. Among the existing varieties, Dutch Robjin has been used for processing crisps while the Tigoni variety has been used for processing into French fries. Many advanced potato clones from the International Potato Centre (CIP), Lima-Peru were introduced into the national potato breeding programme where they underwent multilocation trials and at least six of them passed through the national performance trials in collaboration with the Kenya Plant Health Inspectorate Service (KEPHIS). Out of the national performance trials, three clones were released for multiplication in April 2010 as varieties after indicating good agronomic performance and processing potential.

Detailed information on the processing characteristics of the new and promising cultivars is required in order to support the expanding potato crisps and French fries industry with quality raw materials.

The physical and chemical factors that affect the crisps and French fries depend on cultural practices, environmental conditions and genotype [5]. The genetic component, however, has the strongest influence since the traits are heritable $[5,6]$. The major indicators of suitable potato tubers as a raw material for processing include high dry matter content, good product color and texture, and the amount of oil absorbed during frying. This study was instituted to evaluate the performance of three newly released Kenyan potato varieties for their suitability as raw materials for French fries and potato crisps processing.

\section{MATERIALS AND METHODS}

\section{Production of Potatoes for processing}

Three newly released potato varieties namely: Golden Purple, Kenya Mpya and Sherekea and two established varieties Tigoni and Dutch Robjin were grown under the standard conditions at the National Potato Research Center, Tigoni, Kenya (2100 $\mathrm{m}$ above sea level) in the year 2010 [7]. The variety Tigoni provided control samples for French fries while Dutch Robjin was used as a control for crisps. After maturity, the crop was dehaulmed two weeks before harvesting. Following harvest, the tubers were allowed to cure in a common dark store under ambient air conditions (17-22 $\left.{ }^{\circ} \mathrm{C} / 84-92 \% \mathrm{RH}\right)$ for three weeks at the National Potato Research Center, Tigoni. The 
tubers were thereafter analyzed for physical-chemical characteristics and processed into French fries in Tigoni. Crisping quality evaluation was carried out at a crisps processing company. The dry matter content determination and reducing sugars extraction were done at the Department of Food Science, Nutrition and Technology, University of Nairobi while reducing sugars levels, color and texture analysis were done at Jomo Kenyatta University of Agriculture and Technology.

\section{Determination of physical tuber characteristics}

The physical tuber characteristics (shape, size, skin and flesh color, and eye depth), were determined according to the methods described by Kabira and Lemaga [5] and Abong' et al. [6].

\section{Determination of tuber shape, size and eye depth}

Tuber shape, size and eye depth were analyzed by a method described by Abong' et al. [8]. Round tubers with shallow or medium eye depths and of size $40-60 \mathrm{~mm}$ in diameter were considered suitable for crisps processing while the round oval tubers of size $50 \mathrm{~mm} \leq$ were considered suitable for French fries.

\section{Determination of skin and flesh color}

Skin and flesh color were determined according to a method described by Abong' et al.[8].

\section{Determination of specific gravity and dry matter content}

Specific gravity was determined in the raw tubers according to weight under water method as described by Ludwig [9]. Tubers with specific gravity of $\geq 1.070$ were considered suitable for processing. For determination of dry matter, five whole tubers were randomly selected from each cultivar and cut into small slices (1-2 mm) and mixed thoroughly. Dry matter contents were then determined by drying triplicate $20 \mathrm{~g}$ samples at $80{ }^{\circ} \mathrm{C}$ for $72 \mathrm{hr}$ in a forced air oven. Tubers with dry matter contents $\geq 20$ $\%$ were considered ideal for crisps and French fry processing.

\section{Determination of oil content}

After drying, potato crisps were finely ground in a blender and triplicate $5 \mathrm{~g}$ samples were accurately weighed and placed into thimbles. They were extracted in Soxhlet apparatus using analytical grade petroleum ether (boiling point $40-60{ }^{\circ} \mathrm{C}$ ) for $16 \mathrm{~h}$ as described by Lulai and Orr [10]. The petroleum ether was evaporated away in a rotary vacuum evaporator and the residual oil dried in an air-oven at $80{ }^{\circ} \mathrm{C}$ for $2 \mathrm{~h}$. The weight of the residue was calculated as percent oil content.

\section{Extraction and determination of reducing sugars}

Approximately $10 \mathrm{~g}$ of homogenized potato slices and finely ground crisps were weighed into a $250 \mathrm{ml}$ conical flask and $50 \mathrm{ml}$ of $96 \%$ alcohol was added and mixed well. The mixture was refluxed at $100{ }^{\circ} \mathrm{C}$ for 1 hour, stirring occasionally. The resultant slurry was filtered and the filtrate collected. The conical flask was rinsed 3 times with $5 \mathrm{ml}$ of $80 \%$ alcohol. The filtrate was transferred into $150 \mathrm{ml}$ pear-shaped flask and the solvent evaporated to dryness at $60{ }^{\circ} \mathrm{C}$. Approximately $10 \mathrm{ml}$ of distilled water was added to the dried sample. Thereafter the dissolved sample was 
placed in duplicates of $2 \mathrm{ml}$ into a test tube and $2 \mathrm{ml}$ of diethyl ether added. The mixture was vigorously shaken and allowed to stand before removing the ether layer. This was repeated 3 times. Excess ether was flashed off using a vacuum (Heraeus, RVT 360, Germany). Equal amounts of acetonitrile were added to the samples before being stored at $5{ }^{\circ} \mathrm{C}$ ready for determination of sugars using HPLC.

The samples were micro-filtered to remove any debris before injecting $20 \mu \mathrm{l}$ into a HPLC, SCL-10A (Shimadzu, Tokyo, Japan) fitted with a Refractive Index Detector, RID-6A (Shimadzu, Tokyo, Japan). Chromatographic conditions included a mobile phase of acetonitrile: water (75:25) pumped through a reverse phase column, $\mathrm{NH}_{2} 100 \mathrm{R} 250 \times 4.6 \mathrm{~mm}, 5 \mu \mathrm{m}$ at a working maximum pressure of $150 \mathrm{kgf} / \mathrm{cm}^{2}$ and flow rate of $1.0 \mathrm{ml} / \mathrm{min}$. Oven temperature was set at $30{ }^{\circ} \mathrm{C}$. Using working standards of sucrose, fructose and glucose, the sugars in the samples were identified and calculated. The results presented are means of duplicate determinations and are given as fructose, glucose and sucrose in $\mathrm{g} / 100 \mathrm{~g}$ dry weight (dw). Tubers of total reducing sugar levels $\leq 0.25 \%$ were considered acceptable for processing.

\section{Processing trials}

Potato tubers were peeled, and sliced using an automatic electric slicer (Hitech Systems, Saudi Arabia) to a uniform thickness of $1.5 \mathrm{~mm}$. The slices were thereafter washed in cold tap water to remove surface starch followed by dewatering using a centrifuge (PPM No. 824, Sweden) at $3000 \mathrm{rpm}$ for $4 \mathrm{~min}$. The potato slices were then fried in an institution size, batch type deep oil fryer (E 6 ARO S.A., La Neuveville, Switzerland) containing about 10 litres of corn oil maintained at a fixed temperature of $170^{\circ} \mathrm{C}$ for 3-5 min. The fried slices were removed and excess oil drained off for 1 min, placed on plates, cooled and taken for evaluation.

For French fries processing, tubers were hand peeled and sliced into 12 x $12 \mathrm{~mm}$ sizes using a hand operated chipper before being washed, dried and fried at a fixed temperature of $170^{\circ} \mathrm{C}$ for 6-8 min.

\section{Color measurements}

French fries and potato crisps color was measured with a color spectrophotometer NF 333 (Nippon Denshoku, Japan) using the CIE Lab L*, $a^{*}$ and b* color scale. The ' $\mathrm{L}^{*}$ ' value is the lightness parameter indicating degree of lightness of the sample; it varies from $0=$ black to $100=$ white. The ' $a *$ ' which is the chromatic redness parameter whose value means tending to red color when positive $(+)$ and green color when negative $(-)$. The ' $\mathrm{b}^{*}$ ' is yellowness chromatic parameter corresponding to yellow color when it is positive $(+)$ and blue color when it is negative (-). Each sample consisted of 10 fries and crisps slices, each of which was measured twice.

\section{Texture measurements}

Fries and crisps texture measurements were performed at room temperature $\left(20{ }^{\circ} \mathrm{C}\right)$ by a puncture test performed in a Texture Analyzer, Sun Rheometer Compac 100 (Sun scientific co. Ltd, Japan) equipped with a wedge probe imitating front teeth. Maximum force needed at a penetration rate of $100 \mathrm{~mm} / \mathrm{min}$ was recorded. Maximum Force (MF) was defined as the force at which the wedge penetrates the outer layer of 
the surface of the fried potato fries and crisps slices [11]. Each measurement was conducted on 10 potato fries and crisps as described by Vliet et al. [12].

\section{Sensory evaluation}

For sensory evaluation, coded samples were presented to 15 panelists, all familiar with potato crisps. Panel members scored for flavor, oiliness and overall acceptability on a 7-point hedonic rating scale varying from 1(dislike very much) to 7 (like very much). A score of 4 was the lower limit of acceptability [13].

\section{Data analysis}

All the experiments were replicated two times, and the average values reported. Analysis of variance (ANOVA) and least significant difference test for the variables were conducted using the Statistical Analysis System (SAS version 9). Pearson correlation analysis was also performed to determine linear relationships where necessary. Differences at $\mathrm{p} \leq 0.05$ were considered significant.

\section{RESULTS}

\section{Physical tuber characteristics}

The physical tuber quality characteristics of the five Kenyan potato varieties are given in Table 1. All the varieties, with exception of Golden Purple and Tigoni which had a mixture of round pointed and oval shapes, were round in shape. Tigoni and Kenya Mpya varieties had white, cream skin colors; Dutch Robjin and Sherekea were red while Golden Purple was dark-purple on the skin. Dutch Robjin and Sherekea had tubers with medium eye depths while Golden Purple and Tigoni tubers had shallow eye depths.

\section{Tuber size, specific gravity, dry matter, moisture and oil content}

Tuber size (diameter) varied significantly $(\mathrm{P} \leq 0.05)$ with the varieties. It ranged from $43 \mathrm{~mm}$ in Golden Purple to $55.50 \mathrm{~mm}$ in Kenya Mpya (Table 2). All the cultivars had tuber sizes within recommended range for crisps (40-60 mm) and French fries (45 $\mathrm{mm} \leq)$. There was no significant $(\mathrm{P}>0.05)$ effect of variety on specific gravity. All the varieties had specific gravity greater than 1.080 that is recommended for crisps and French fries processing (Kabira and Lemaga, 2006). Dry matter contents, however, differed significantly $(\mathrm{P} \leq 0.05)$ among the varieties. Dry matter content ranged from $20.81 \%$ in Golden Purple to $25.77 \%$ in Kenya Mpya. Crisps oil content varied significantly $(\mathrm{P} \leq 0.05)$ from $31.28 \%$ in Kenya Mpya to $36.80 \%$ in Golden purple while it ranged from $7.51 \%$ to $8.81 \%$ in French fries of the same varieties. Dry matter content was negatively correlated to oil contents of crisps and French fries (Figures 1 and 2). Regression lines, $Y=54.85-0.9155 X$ and $Y=56.263-4.019 X$ were found suitable to estimate final oil contents (Y) of crisps and French fries, respectively, on the basis of dry matter content $(\mathrm{X})$ in potato cultivars. 

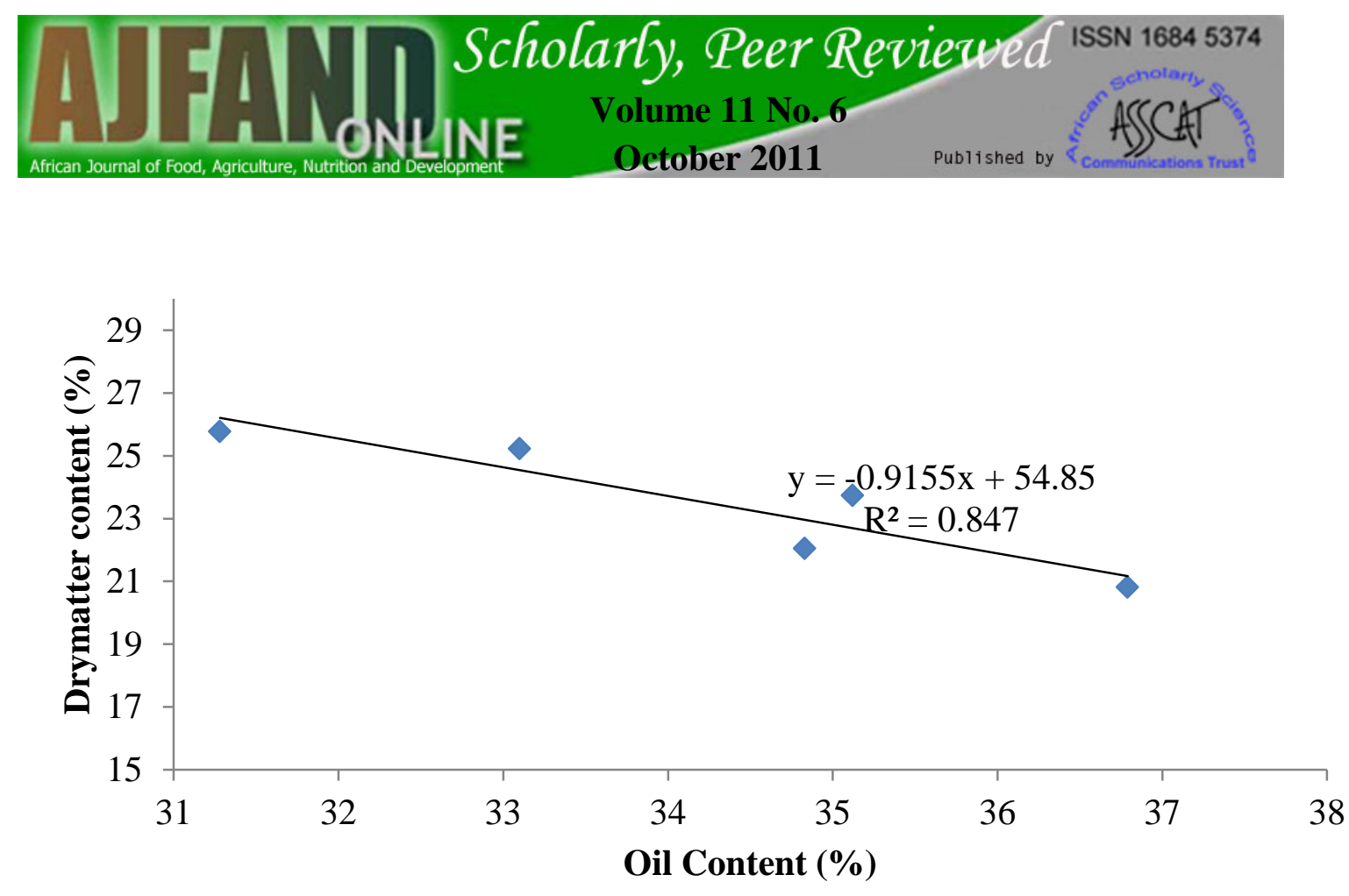

Figure 1: Correlation of dry matter content in raw potato tubers and oil content of potato crisps

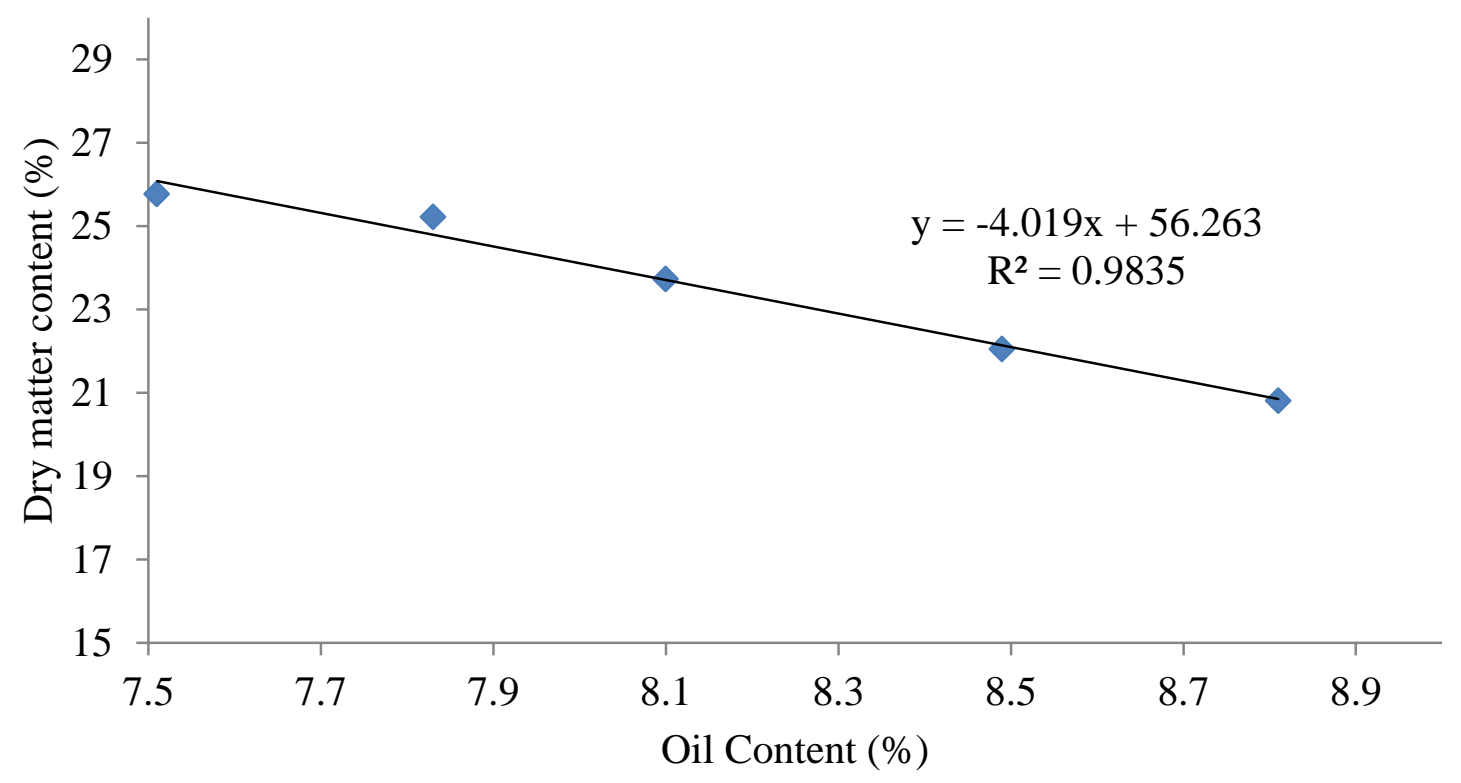

Figure 2: Correlation of dry matter content in raw potato tubers and oil content of French fries

Levels of reducing sugars in potato tubers

Table 3 shows a summary of the levels of reducing sugars in tubers of the five potato varieties. Total reducing sugars significantly $(\mathrm{P} \leq 0.05)$ varied among the cultivars ranging from 0.099 \% in Dutch Robjin to 0.106 \% in Kenya Mpya. It is expected therefore, that all the cultivars would produce products of good and attractive colors due to the low levels reducing sugars. 


\section{Color and Textural properties of crisps and French fries}

Significant $(\mathrm{P} \leq 0.05)$ varietal differences in color and textural properties of crisps and French fries were noted (Table 4). Fries and crisps from all the varieties produced light colored products $\left(\mathrm{L}^{*}>50\right)$ with Golden Purple and Tigoni producing the lightest crisps and French fries, respectively. Crisps and fries from all the cultivars tended towards green as shown by the negative values of redness parameter $\left(a^{*}\right)$ indicating that there was less or no excess browning of the products during frying. All the products tended towards yellow as indicated by positive values of yellowness parameter (b*). It was, however, noted that French fries from Kenya Mpya had very low values (13.73) compared to those of the other four varieties. Textural properties differed significantly $(\mathrm{P} \leq 0.05)$ with the product and variety.

\section{Sensory quality characteristics}

All the sensory attributes evaluated with the exception of crisps color significantly differed $(\mathrm{P} \leq 0.05)$ with the variety (Table 5$)$. Crisps color scores were generally higher in all the cultivars compared to French fries colors which significantly scored lower in Golden Purple (4.2) and Kenya Mpya that scored below acceptable limit (3.6). Flavor perception was generally acceptable in all the varieties and for all the products. It was, however, notable that the flavor scores were lower (4.1) for French fries processed from Kenya Mpya and Golden Purple. There were no significant ( $\mathrm{P}>$ 0.05 ) correlations between sensory color scores and the $\mathrm{L}^{*}, \mathrm{a}^{*}$ parameters of French fries. There was, however, significantly $(\mathrm{P} \leq 0.001)$ high correlation $(\mathrm{r}=0.88)$ between sensory color scores and the yellowness $\left(b^{*}\right)$ parameter (Table 6$)$. This means that consumers will be able to differentiate the color differences.

\section{DISCUSSION}

Tuber shape has been known to influence peeling and trimming efficiency during processing. Potato tubers that are round in shape are suitable for crisps processing for most processors especially in Kenya due to ease of handling [5, 4]. The round oval or pointed tubers, however, lend themselves easily for processing of French fries. It is not prohibitive, however, for the round tubers to be used in French fry processing so long as they meet the size specification [6]. White or red skin colors are associated with good quality by many Kenyan consumers. The Golden Purple is an exception since it is a rare appearance whose popularity may only be determined by the consumers and processing quality over time. All the varieties had tubers with either shallow or medium eye depths which make them suitable for processing with minimal losses during peeling and trimming with overall good yields of crisps and French fries. Tuber size directly influences crisp and French fries size, which in turn influences post-frying handling. Larger tubers are ideal for French fries processing. However, larger tubers of more than $60 \mathrm{~mm}$ in diameter yield crisps which are fragile and break easily during packaging and transport [5]. Golden Purple and Sherekea would be ideal for crisps and short fries while Tigoni and Kenya Mpya can be used for French fries processing.

Potato tuber dry matter content is a very important attribute that determines suitability of varieties for processing. Tubers with high specific gravity and dry matter contents 
are known to give higher yields and absorb less oil and hence more economical to process $[10,14]$. Based on specific gravity and dry matter content selection criteria, all cultivars were suitable for processing. Oil uptake by potato crisps and French fries was shown to be affected by variety which also influences dry matter content. Similar causal effects have been established in related studies $[8,15,16]$. To minimize the oil uptake and improve the yield the processing industry, Gravoueille [15] proposed dry matter content levels of between $23 \%$ and $25 \%$. However, potatoes with high dry matter (>20 \%) have been shown to produce high yield of products with lower oil content than those of lower dry matter [16]. A linear relationship between dry matter content of sweet potatoes and oil uptake similar to results of this study was found by Hagenimana et al. [17]. It is important to note that many factors have been reported to affect oil uptake into crisps and French fries, including frying temperature and duration, product shape and solid content. Oil uptake during frying has been, however, known to be a complex phenomenon resulting from interactions between oil and products that undergo numerous physical, chemical, and structural transformations during frying [18].

In the current study, variety influenced reducing sugars. These results are in agreement with those reported by Kumar et al. [19] who demonstrated that genetic makeup had a strong influence on reducing sugars. Reducing sugars especially glucose reacts with amino acids in a non-enzymic browning reaction during frying of potato products which gives them a golden brown color. The levels of reducing sugars present in the potato tuber therefore, determine the extent of browning during frying. Very high levels of reducing sugars results in undesirable dark brown crisps as opposed to the more desirable golden brown color [8, 20, 21, 22]. All the cultivars in the present study had required levels of reducing sugars $(\leq 0.25 \%)$ for processing. It is therefore, expected that crisps and French fries made from the five cultivars shall be of attractive color.

Fries and crisps from all the varieties produced light colored products $\left(\mathrm{L}^{*}>50\right)$ which indicates that there was no excessive darkening. This can be attributed to low reducing sugars levels exhibited by the varieties in this study. Crisps and fries from all the cultivars tended towards green as shown by the negative values of redness parameter $\left(\mathrm{a}^{*}\right)$ indicating that there was less or no excess browning of the products during frying. Lack of excess browning can be attributed to low and acceptable levels of sugars, major causes of browning during frying of potato products. The maximum force $(\mathrm{N})$ was generally high for crisps which are normally sliced and brittle compared to French fries which are crunchy and mealy. As indicated by Abong' et al. [3], crisps are generally low in moisture content and hence would exhibit high textural values in comparison to French fries.

Color is a critical sensory property that known to determine acceptability of a food product [23] and hence must conform to consumer requirement [24]. It therefore follows that variety Kenya Mpya may be a good choice for crisps but not French fries processing since they failed the sensory threshold of acceptance. All crisps and fries from the five cultivars were acceptable in terms of texture and oiliness with notable lower scores in French fries processed from Kenya Mpya. Although all the varieties 
had acceptable scores in overall acceptability, crisps processed from varieties Golden Purple, Kenya Mpya and Tigoni scored comparably to Dutch Robjin, a variety used by most processors in Kenya [4]. They would therefore serve as attractive alternatives in seasons of scarcity. On the other hand, Kenya Mpya and Golden Purple varieties had lower scores compared to Sherekea and Dutch Robjin varieties which were comparable to Tigoni, a Kenyan chipping variety [6].

\section{CONCLUSION AND RECOMMENDATION}

The new varieties, Kenya Mpya, Sherekea and Golden Purple in descending order of preference could be used to produce crisps comparable to Dutch Robjin, an established crisping Kenyan potato variety. With the exception of Kenya Mpya, new varieties Sherekea, and Golden Purple produced good French fries comparable to the high chipping quality variety, Tigoni. The Tigoni variety also proved to be a good raw material not only for French fries, but also acceptable crisps. The new varieties therefore form an additional pool of raw materials for processing of crisps and French fries in Kenya and should be promoted alongside the established ones for processors to have adequate raw materials throughout the year.

\section{ACKNOWLEDGEMENTS}

Authors are grateful to Kenya Agricultural Productivity Programme and Agribusiness Project (KAPAP) and the National Potato Research Centre (KARI) for financial support. We acknowledge the role played by potato breeders; Dr. J. Landeo (CIP), Mr. S. Nderitu and Mr. J. Onditi (NPRC) who ensured that the materials were available. We appreciate the Food Science Department team at KARI-Tigoni led by Mrs. N. Ngone and Mr. K. Bethuel who offered their service during sample preparation and evaluation. Laboratory analysis was accomplished with assistance from Mr. J. M’Thika and Ms. R. Kamau, Laboratory Technicians at the University of Nairobi, and J.N. Karanja from the Jomo Kenyatta University of Agriculture and Technology. The authors appreciate the support and assistance accorded by the management of Deepa Industries Ltd where processing trials were carried out. 


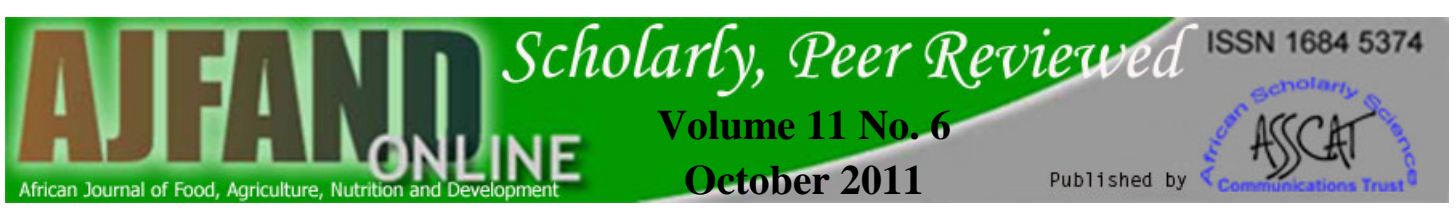

Table 1: Physical tuber quality characteristics of five Kenyan potato varieties

\begin{tabular}{lllll}
\hline Cultivar & Shape & Skin color & Flesh color & Eye depth \\
\hline Tigoni & Round oval & Cream & Cream & Shallow \\
Dutch Robjin & Round & Red & Cream-yellow & Medium \\
Sherekea & Round & Red & White & Medium \\
Kenya Mpya & Round & Cream & White & Shallow \\
Golden Purple & Round pointed & Dark-purple & Cream & Shallow \\
\hline
\end{tabular}

Table 2: Tuber diameter, specific gravity, dry matter and oil content ${ }^{1}$

\begin{tabular}{lllllll}
\hline Cultivar & Diameter $(\mathbf{m m})$ & $\begin{array}{l}\text { Dry matter } \\
\text { content (\%) }\end{array}$ & $\begin{array}{l}\text { Specific } \\
\text { gravity }\end{array}$ & $\begin{array}{l}\text { Moisture } \\
\text { content (\%) }\end{array}$ & $\begin{array}{l}\text { Crisps oil } \\
\text { content (\%) }\end{array}$ & $\begin{array}{l}\text { French fries oil } \\
\text { content (\%) }\end{array}$ \\
\hline Dutch Robjin & $49.50 \pm 0.41 \mathrm{~d}$ & $25.22 \pm 0.10 \mathrm{~b}$ & $1.10 \pm 0.03 \mathrm{a}$ & $1.95 \pm 0.08 \mathrm{a}$ & $33.10 \pm 0.17 \mathrm{~d}$ & $7.83 \pm 0.07 \mathrm{~d}$ \\
Golden Purple & $43.00 \pm 0.01 \mathrm{e}$ & $20.81 \pm 0.26 \mathrm{e}$ & $1.08 \pm 0.00 \mathrm{a}$ & $1.99 \pm 0.11 \mathrm{a}$ & $36.79 \pm 0.11 \mathrm{a}$ & $8.81 \pm 0.78 \mathrm{a}$ \\
Kenya Mpya & $55.50 \pm 0.50 \mathrm{a}$ & $25.77 \pm 0.13 \mathrm{a}$ & $1.13 \pm 0.01 \mathrm{a}$ & $1.91 \pm 0.16 \mathrm{a}$ & $31.28 \pm 0.07 \mathrm{e}$ & $7.51 \pm 0.06 \mathrm{e}$ \\
Sherekea & $50.00 \pm 1.18 \mathrm{c}$ & $23.73 \pm 0.20 \mathrm{c}$ & $1.09 \pm 0.00 \mathrm{a}$ & $1.39 \pm 0.08 \mathrm{~b}$ & $35.12 \pm 0.14 \mathrm{~b}$ & $8.10 \pm 0.03 \mathrm{c}$ \\
Tigoni & $52.00 \pm 0.10 \mathrm{~b}$ & $22.05 \pm 0.06 \mathrm{~d}$ & $1.09 \pm 0.02 \mathrm{a}$ & $1.82 \pm 0.07 \mathrm{a}$ & $34.83 \pm 0.25 \mathrm{c} \quad 8.49 \pm 0.08 \mathrm{~b}$
\end{tabular}

Values with the same letters in the same column are not significantly different at $\mathrm{P} \leq$ 0.05 .

Results are means of two determinations \pm standard deviation

Oil content is reported on wet weight basis 
Table 3: Levels of reducing sugars ( $\mathrm{g} / 100 \mathrm{~g}$ wet weight basis) in tubers of five Kenyan potato varieties

\begin{tabular}{lllll}
\hline Cultivar & Fructose & Glucose & Sucrose & $\begin{array}{l}\text { Total reducing sugars } \\
\text { contents }\end{array}$ \\
\hline Dutch & $0.022 \pm 0.000$ & $0.022 \pm 0.000$ & $0.055 \pm 0.001$ & $0.099 \pm 0.003$ \\
Golden Purple & $0.031 \pm 0.013$ & $0.016 \pm 0.002$ & $0.056 \pm 0.002$ & $0.103 \pm 0.002$ \\
Sherekea & $0.026 \pm 0.002$ & $0.023 \pm 0.008$ & $0.055 \pm 0.053$ & $0.104 \pm 0.042$ \\
Kenya Mpya & $0.023 \pm 0.004$ & $0.018 \pm 0.003$ & $0.065 \pm 0.021$ & $0.106 \pm 0.014$ \\
Tigoni & $0.025 \pm 0.003$ & $0.029 \pm 0.001$ & $0.049 \pm 0.001$ & $0.103 \pm 0.005$ \\
\hline
\end{tabular}

Values with the same letters in the same column are not significantly different at $\mathrm{P} \leq$ 0.05 .

Results are means of two determinations \pm standard deviation 
Table 4: Color and textural properties of crisps processed from five Kenyan potato varieties

\begin{tabular}{|c|c|c|c|c|c|}
\hline Variety & Product & Lightness (L*) & Redness (a*) & Yellowness (b*) & Texture (N) \\
\hline \multirow[t]{2}{*}{ Golden Purple } & Crisps & $70.89 \pm 3.35 a$ & $-0.74 \pm 1.11 b$ & $22.89 \pm 1.57 a$ & $0.34 \pm 0.14 a$ \\
\hline & French fries & $68.52 \pm 1.42 \mathrm{ab}$ & $-5.87 \pm 1.40 \mathrm{c}$ & $18.57 \pm 3.40 c$ & $0.23 \pm 0.01 c$ \\
\hline \multirow[t]{2}{*}{ Sherekea } & Crisps & $68.86 \pm 1.68 \mathrm{ab}$ & $0.20 \pm 0.81 \mathrm{ab}$ & $22.09 \pm 2.61 \mathrm{a}$ & $0.41 \pm 0.04 a$ \\
\hline & French fries & $68.32 \pm 0.77 a b$ & $-1.48 \pm 0.72 \mathrm{a}$ & $22.43 \pm 2.47 b$ & $0.29 \pm 0.04 b$ \\
\hline \multirow[t]{2}{*}{ Dutch Robjin } & Crisps & $68.09 \pm 1.51 b$ & $-0.40 \pm 0.57 a$ & $23.56 \pm 2.35 a$ & $0.36 \pm 0.03 a$ \\
\hline & French fries & $66.50 \pm 3.45 b$ & $-3.41 \pm 0.19 b$ & $26.21 \pm 2.18 a$ & $0.36 \pm 0.08 a$ \\
\hline \multirow[t]{2}{*}{ Kenya Mpya } & Crisps & $66.72 \pm 3.50 b$ & $0.43 \pm 0.64 a$ & $21.97 \pm 3.22 \mathrm{a}$ & $0.36 \pm 0.01 a$ \\
\hline & French fries & $66.78 \pm 2.24 b$ & $-3.72 \pm 0.56 b$ & $13.73 \pm 1.13 \mathrm{~d}$ & $0.29 \pm 0.01 b$ \\
\hline \multirow[t]{2}{*}{ Tigoni } & Crisps & $67.98 \pm 1.19 b$ & $0.44 \pm 0.77 a$ & $22.31 \pm 2.11 a$ & $0.41 \pm 0.04 a$ \\
\hline & French fries & $69.24 \pm 0.67 a$ & $-3.72 \pm 0.89 b$ & $21.14 \pm 4.56 b c$ & $0.26 \pm 0.03 b c$ \\
\hline
\end{tabular}

Values with the same letters in the same column are not significantly different at $\mathrm{P} \leq$ 0.05 .

Results are means \pm standard deviation 


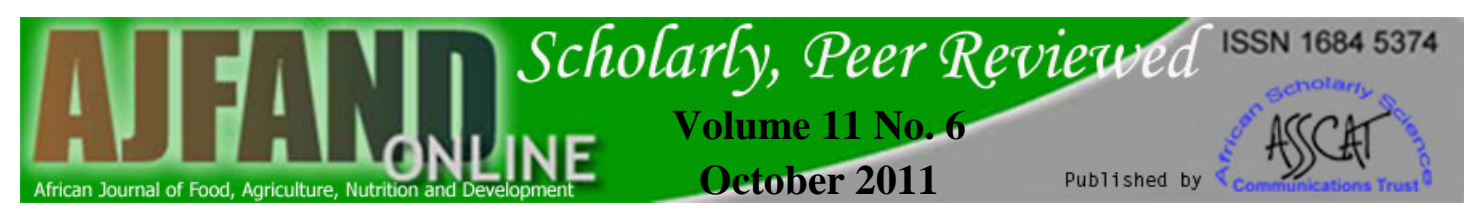

Table 5: Sensory characteristics of French fries and crisps processed from five Kenyan potato varieties

\begin{tabular}{lllllll}
\hline Cultivar & & Color & Flavor & Texture & Oiliness & $\begin{array}{l}\text { Overall } \\
\text { acceptability }\end{array}$ \\
\hline Dutch Robjin & French fries & $5.8 \pm 0.8 \mathrm{a}$ & $5.7 \pm 0.8 \mathrm{a}$ & $5.7 \pm 0.9 \mathrm{a}$ & $5.6 \pm 0.3 \mathrm{a}$ & $5.7 \pm 0.8 \mathrm{ab}$ \\
& Crisps & $5.7 \pm 0.7 \mathrm{ab}$ & $5.4 \pm 0.5 \mathrm{a}$ & $5.8 \pm 0.4 \mathrm{a}$ & $5.5 \pm 0.5 \mathrm{a}$ & $5.5 \pm 0.4 \mathrm{a}$ \\
Golden Purple & French fries & $4.2 \pm 0.6 \mathrm{c}$ & $4.1 \pm 0.4 \mathrm{~b}$ & $4.4 \pm 0.6 \mathrm{c}$ & $4.7 \pm 0.9 \mathrm{~b}$ & $4.7 \pm 0.4 \mathrm{c}$ \\
& Crisps & $5.7 \pm 0.8 \mathrm{ab}$ & $5.1 \pm 0.9 \mathrm{ab}$ & $5.5 \pm 1.0 \mathrm{a}$ & $5.3 \pm 0.9 \mathrm{ab}$ & $5.5 \pm 0.3 \mathrm{a}$ \\
& French fries & $3.6 \pm 0.7 \mathrm{cb}$ & $4.1 \pm 0.8 \mathrm{~b}$ & $4.1 \pm 0.3 \mathrm{~d}$ & $4.2 \pm 0.7 \mathrm{c}$ & $4.1 \pm 0.2 \mathrm{~d}$ \\
Kenya Mpya & Crisps & $5.8 \pm 0.6 \mathrm{a}$ & $5.5 \pm 0.8 \mathrm{a}$ & $5.6 \pm 0.8 \mathrm{a}$ & $5.4 \pm 1.0 \mathrm{a}$ & $5.5 \pm 0.9 \mathrm{a}$ \\
& French fries & $5.1 \pm 1.1 \mathrm{~b}$ & $5.5 \pm 1.0 \mathrm{a}$ & $5.2 \pm 0.9 \mathrm{~b}$ & $4.8 \pm 1.2 \mathrm{~b}$ & $5.3 \pm 1.1 \mathrm{~b}$ \\
Sherekea & Crisps & $5.3 \pm 0.8 \mathrm{~b}$ & $4.8 \pm 0.6 \mathrm{~b}$ & $5.0 \pm 0.7 \mathrm{~b}$ & $4.8 \pm 1.0 \mathrm{c}$ & $4.9 \pm 0.8 \mathrm{~b}$ \\
& French fries & $5.9 \pm 0.5 \mathrm{a}$ & $5.8 \pm 0.9 \mathrm{a}$ & $5.5 \pm 0.7 \mathrm{a}$ & $5.1 \pm 0.9 \mathrm{~b}$ & $6.0 \pm 0.8 \mathrm{a}$ \\
& Crisps & $5.8 \pm 0.8 \mathrm{a}$ & $5.1 \pm 1.1 \mathrm{ab}$ & $5.1 \pm 0.7 \mathrm{~b}$ & $4.9 \pm 1.2 \mathrm{bc}$ & $5.1 \pm 0.9 \mathrm{ab}$
\end{tabular}

Values with the same letters in the same column are not significantly different at $\mathrm{P} \leq$ 0.05. Evaluation was done on Point hedonic scale. A score of 4 was the acceptable lower limit.

All figures are mean \pm standard deviation

Table 6: Pearson correlation coefficient (r) between sensory color scores and Yellowness parameter of French fries made from five varieties

\begin{tabular}{lcc}
\hline Parameters & Yellowness (b*) & Sensory color score \\
\hline Yellowness $\left(\mathrm{b}^{*}\right)$ & 1.00 & $-.88^{\mathrm{a}}$ \\
Sensory color score & $-0.88^{\mathrm{a}}$ & 1.00 \\
\hline
\end{tabular}

${ }^{\mathrm{a}}$ Significant correlation coefficient $(\mathrm{P} \leq 0.05) .(\mathrm{N}=24)$ 


\section{REFERENCES}

1. GOK. Ministry of Agriculture Potato Standards In: The Crop Production and Livestock Act. Kenya Gazette supplements no.38, Nairobi. 2007.

2. Walingo A, Lung'aho C, N'gang'a N, Kinyae PM and JN Kabira Potato marketing, storage, processing and utilization in Kenya. Proceedings of $6^{\text {th }}$ Triennial congress of the African potato Association, Agadir, Morocco. 2004.

3. Abong' GO, Okoth MW, Imungi JK and JN Kabira Consumption patterns diversity and characteristics of potato crisps in Nairobi, Kenya. J. Applied Biosci. 2010a; 32: 1942 - 1955.

4. Abong' GO, Okoth MW, Imungi JK and JN Kabira Characteristics of the potato crisps processing industry in Kenya. J. Animal and Plant Sci. 2010b; 8 (1): 936- 943.

5. Kabira JN and B Lemaga Potato Processing: Quality Evaluation procedures for research and food industries applications in East and Central Africa. Kenya Agricultural Research Institute, Nairobi, Kenya. 2006.

6. Abong' GO, Okoth MW, Karuri EG, Kabira JN and FM Mathooko Levels of reducing sugars in eight Kenyan potato cultivars as influenced by stage of maturity and storage conditions. J. Anim. and Plant Sci. 2009; 2 (2): 76 - 84.

7. Lung'aho $\mathbf{C}$ and JN Kabira A guide to growing table potatoes. Kenya Agricultural Research Institute, Nairobi, Kenya. 1999.

8. Abong' GO, Okoth MW, Imungi JK and JN Kabira Evaluation of selected Kenyan potato cultivars for processing into potato crisps. Agric. Bio. J. North Amer. 2010c; 1(5): 886-893.

9. Ludwig JW Determination of the dry matter content of potatoes by weighing in water. Institute for Storage and Processing of Agricultural Produce (IBVL), Wageningen, Holland. 1972.

10. Lulai E and PH Orr The influence of specific gravity on oil content of chips. Am. Potato J. 1979; 56: 379-390.

11. Segnini S, Dejmek P and R O“ste, Reproducible texture analysis of potato chips. J. Food Sci. 1999; 64: 309-312.

12. Vliet T, Jendo E, Visser and $\mathbf{H}$ Luyten On the mechanism by which oil uptake decreases crispy/crunchy behaviour of fried products. Food Res. Int. 2007; 40: 1122-1128.

13. Larmond E Methods for sensory evaluation of food. Food Research Institute, Central Experiment Farm, Canada Dept. of Agriculture, Ottawa. 1977. 
14. Burton WG The potato. $3^{\text {rd }}$ ed. Longman Group United Kingdom. 1989; 286360.

15. Gravoueille JM Utilisation de la pomme de terre pour l'alimentation humaine. In La pomme deterre. Production, Amelioration, Ennemis et Maladies, Utilisations, (P. Rousselle, Y. Robert, and J.C. Crosnier, eds.). INRA, Paris, France. 1996; 452-498.

16. Abong' GO, Okoth MW, Karuri EG, Kabira JN and FM Mathooko Influence of potato cultivar and stage of maturity on oil content of French fries made from eight Kenyan potato cultivars. Afri. J. Food Agric. Nut. and Dev. 2009b; 9 (8): 16667-1682.

17. Hagenimana V, Karuri EG and MA Oyunga Oil content in fried processed sweet potato products. J. Food Proc. and Pres. 1998; 22: 123-137.

18. Ziaiifar MA, Achir N, Courtois F, Trezzani I and G Trystram Review of mechanisms, conditions, and factors involved in the oil uptake phenomenon during the deep-fat frying process. Int. J. Food Sci. and Tech. 2008; 43: 14101423.

19. Kumar D, Singh BP and $\mathbf{P}$ Kumar An overview of the factors affecting sugar content of potatoes. Central Potato Research Institute, Ann. Appl. Biol. 2004; 145: 247-256.

20. Hamernik AJ and JRE Hanneman Breeding haploid species potato that chip from cold storage. Amer. J. Potato Res. 1998; 75 (6): 278-279.

21. Guar PC, Singh B, Pandey SK, Marwaha RS and D Kumar A new high dry matter potato variety for chipping. Current Sci. 1999; 79:722-724.

22. Olsson K, Svensson $\mathbf{R}$ and $\mathbf{C}$ Roslund Tuber components affecting acrylamide formation and color in fried potato: variation by variety, year, and storage temperature and storage time. J. Sci. Food and Agri.2004; 84 (5): 447 - 458.

23. Surkan S, Albani $\mathbf{O}$ and $\mathbf{L}$ Ramallo Influence of storage conditions on sensory shelf-life of yerba mate. J. Food Qual. 2009; 32: 58-72.

24. Krokida MK, Maroulis ZB and GD Saravacos The effect of method of drying on the color of dehydrated products. Int. J. Food Sci. \& Tech. 2001; 36: 53-59. 